\title{
Antioxidant Potential and Ionomic Analysis of Two Buckwheat Species from Kashmir Region
}

\author{
Tanveer Bilal Pirzadah', Bisma Malik', Inayatullah Tahir ${ }^{1,2}$, Reiaz UI Rehman ${ }^{1 *}$
}

\section{Tanveer Bilal Pirzadah ${ }^{1}$ Bisma Malik', Inayatullah Tahir $^{1,2}$, Reiaz UI Rehman ${ }^{1 *}$}

'Department of Bioresources, University of Kashmir, Srinagar, Jammu and Kashmir, INDIA.

${ }^{2}$ Department of Botany, University of Kashmir, Srinagar, Jammu and Kashmir, INDIA.

\section{Correspondence}

\section{Dr. Reiaz UI Rehman}

Department of Bioresources, University of Kashmir, Srinagar, Jammu and Kashmir, INDIA.

Phone no: +91-9796546222

E-mail: rreiazbiores@gmail.com

\section{History}

- Submission Date: 16-04-2018;

- Review completed: 23-05-2018;

- Accepted Date: 11-07-2018

\section{DOI : 10.5530/pj.2018.6s.16}

Article Available online

http://www.phcogj.com/v10/i6s

\section{Copyright}

(C) 2018 Phcog.Net. This is an openaccess article distributed under the terms of the Creative Commons Attribution 4.0 International license.

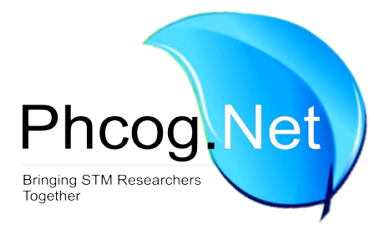

\begin{abstract}
Background: Buckwheat in the past had been the staple food for many regions in the Himalaya's and its utilization has declined with time. In recent times buckwheat gained a lot of attention as it has been placed in the list of underutilized crops by FAO. There is a strong sentiment and realization for buckwheat revival because of its nutraceutrical properties due to which it provides the consumers with extra choice for his food basket. In this context the present investigation aimed to evaluate the antioxidant potential and mineral element analysis of two buckwheat species grown in Kashmir region. Methods: To achieve this goal, antioxidant potential of two buckwheat species was done by using standard protocols. For ionomic analysis, atomic absorption spectrophotometry (AAS) was done to unravel the macro-and micro-nutrient composition. Result: Aqueous extract of Fagopyrum tataricum exhibits higher TPC (159.51 $\pm 10.3 \mathrm{mg}$ gallic acid equivalent $\left.\mathrm{g}^{-1} \mathrm{DW}\right)$ and TFC $(79.49 \pm 9.76 \mathrm{mg}$ rutin equivalent $\left.\mathrm{g}^{-1} \mathrm{DW}\right)$. The $F$. tataricum samples exhibit high radical scavenging activity $\left(\mathrm{RS}_{\mathrm{a} 50}=26.67 \mu \mathrm{g} \mathrm{ml}^{-1}\right)$ as compared to $F$. kashmirianum $\left(R S=34.15 \mu \mathrm{g} \mathrm{ml}^{-1}\right.$ ). Elemental analysis revealed that calcium (Ca) was found high in F. tataricum $(5125 \pm 56.76 \mathrm{ppm})$ while as the iron (Fe) and zinc (Zn) were found in high concentration in F. kashmirianum $(1122.5 \pm 25.77 \mathrm{ppm})$ and $(122.75 \pm 12.34 \mathrm{ppm})$ respectively. Conclusion: These findings suggested that buckwheat extract possess excellent antioxidant property and is rich source of minerals indispensable for human health. Thus, buckwheat could be a promising alternative in functional food sector for improving the social well-being and diminishing malnutrition especially for the impoverished community.

Key words: Aqueous extract, Antioxidants, AAS, Buckwheat, DPPH, FRAP.
\end{abstract}

\section{INTRODUCTION}

Generation of free radicals in the form of active oxygen species (AOS) in biological system is a normal phenomenon. These AOS include; superoxide anions $\left(\mathrm{O}^{-}\right)$, hydrogen peroxide $\left(\mathrm{H}_{2} \mathrm{O}_{2}\right)$, hydroxyl radicles $\left(\mathrm{OH}^{-}\right)$and singlet oxygen $\left({ }_{2} \mathrm{O}^{1}\right) .{ }^{2}$ Previously, AOS were considered as dangerous molecules which must be maintained at low levels in cells. However, this perception has been changed because these serve as important signaling molecules. ${ }^{2}$ Sometimes these free radicles are produced to such an extent that the body's defence system is not able to expel them out and thus leads to oxidative stress. ${ }^{3}$ Under such conditions these AOS cause damage to various cell organelles, cell death, DNA damage and gene mutation which often leads to chronic ailments like neurodegenerative diseases, cardiovascular dysfunctions, aging, weakening of immune system. ${ }^{4}$ Earlier reports suggests that there exists strong association between dietary intake of these natural products and the disease prevention and such wonderful properties of these botanicals is due to the presence of secondary metabolites with healthcare properties. ${ }^{5,6}$ Natural antioxidants are interesting green alternatives to artificial antioxidants because of the safety concerns and limitation of usage. Plants contain plethora of secondary metabolites (e.g, flavonoids, glycosides, terpenoids, tannins etc) with significant antioxidant properties and have an immense potential in pharmaceutical and food sectors. ${ }^{7}$ Buckwheat is among one of them that has gained a rapid momentum in the functional food sector due to its high neutraceutical properties. Buckwheat has attributed worldwide attention, especially from food scientists for its healthy effects over chronic diseases. In developing countries like India, majority of the population rely on traditional system of medicine, besides due to the population explosion the current food production is not sufficient to cater the food crisis so, it is the need of the hour to explore food crops that possess nutritional and medicine value. It is the only pseudocereal that contains a well-known glycoside "rutin". Rutin is known to serve as anti-hypertensive, antiinflammatory, anti-carcinogenic and vasoconstrictive. ${ }^{9}$ Other essential bioactive constituents of tartary buckwheat are phenols, fagopyrins, fagopyritols, resistant starch, dietary fibre, vitamins and lignans. ${ }^{10}$ Buckwheat is also an important source of macro-and micro-nutrients indispensable for human health. ${ }^{11,12}$ reported the $\mathrm{Co} / \mathrm{Sb} / \mathrm{Ba} / \mathrm{Se} / \mathrm{Ag} / \mathrm{Hg} / \mathrm{Cr} / \mathrm{Rb} / \mathrm{Zn} / \mathrm{Fe} / \mathrm{Ni}$ and $\mathrm{Sn}$ contents in the flour and bran of buckwheat, where most trace elements are concentrated mainly 
in the bran. ${ }^{13}$ reported the $\mathrm{Mo} / \mathrm{Ni} / \mathrm{P} / \mathrm{Co} / \mathrm{Cu} / \mathrm{Fe} / \mathrm{Zn}$ and $\mathrm{Mn}$ in extract of buckwheat flour.

To the best of our knowledge, there is scarcity of information regarding the antioxidant potential and elemental concentration analysis in buckwheat species grown in Kashmir region. Keeping in view of the above facts, the present study was conducted to evaluate the antioxidant potential and elemental analysis of two different buckwheat species (Fagopyrum tataricum Gaertn and F. kashmirianum Munshi) grown in Kashmir region.

\section{MATERIALS AND METHODS}

\section{Plant material}

Seeds of Fagopyrum tataricum and F. kashmirianum were procured from Department of Botany, University of Kashmir, Hazratbal, Srinagar. Later these seeds were sown during the month of April-2014 in the Botanical garden of Kashmir University. Harvesting of the leaf sample was done at the pre-flowering stage.

\section{Collection and preparation of sample material}

Fresh and healthy leaves of buckwheat were collected and washed gently with distilled water (without squeezing) to remove debris and dust particles. The plant material is then air-dried under shade at room temperature for 15 days and ground into a powdered form using a surface sterilized mortar and pestle which was further used for extraction.

\section{Solvent extraction procedure}

Preparation of leaf extract was done in aqueous solvent following the protocol of ${ }^{14}$ with slight modifications. Briefly, aqueous leaf extract of F. tataricum and F. kashmirianum was prepared by mixing $5 \mathrm{~g}$ dried fine powder in aqueous solvent and was constantly agitated on a rotatry shaker (200rpm, $25^{\circ} \mathrm{C}$ and $48 \mathrm{~h}$ ). Extract was then filtered through Whatman filter paper (No. 1) and the filtrate was centrifuged $\left(8000 \mathrm{rpm}, 12^{\circ} \mathrm{C}\right.$, $15 \mathrm{~min}$ ) to get clear supernatant. Yield was calculated and $10 \mathrm{mg} / \mathrm{mL}$ was prepared as stock solution which was stored in dark coloured bottles at $4^{\circ} \mathrm{C}$ for further analysis.

\section{Estimation of total phenol content (TPC) and total flavonoid content (TFC)}

The TPC was estimated by Folin-Ciocalteau reagent following the method of. ${ }^{15}$ TFC were investigated by a method described by. ${ }^{16}$ A gallic acid standard $\left(\mathrm{R}^{2}=0.998\right)$ was used to determine the TPC. For the determination of TFC, rutin was used as standard $\left(R^{2}=0.99\right)$.

\section{Ferric Reducing Antioxidant Potential - FRAP assay}

FRAP assay was done using a modified protocol of ${ }^{17}$ based on color (blue) development due to the reduction of the ferric iron $\left(\mathrm{Fe}^{3+}\right)$ to ferrous form $\left(\mathrm{Fe}^{2+}\right)$. FRAP-reagent was freshly prepared by mixing 25mL CH $\mathrm{CH}_{3} \mathrm{COONa}$ buffer (300mM, pH 3.6), $2.5 \mathrm{~mL}$ TPTZ solution $(10 \mathrm{mM}$ TPTZ prepared in $40 \mathrm{mM} \mathrm{HCl})$ and $2.5 \mathrm{~mL} \mathrm{FeCl}_{3}$ solution $(20 \mathrm{mM})$. The mixture was incubated at $37^{\circ} \mathrm{C}$ for $10 \mathrm{~min}$ before use. Different concentrations of the plant extract and standard (10-50 $\mu \mathrm{l})$ were allowed to react with $2 \mathrm{~mL}$ FRAP-reagent for $30 \mathrm{~min}$ in dark. After incubation, the colored solution (ferrous tripyridyltriazine complex) formed was then read at $593 \mathrm{~nm}$. Calibration standard was linear between 200 and $1000 \mu \mathrm{M} \mathrm{FeSO}_{4}$ and the result were expressed in $\mu \mathrm{M} \mathrm{Fe}$ (II)/g DW.

\section{DPPH assay (1, 1-diphenyl 1-2-picryl-hydrazyl)}

DPPH activity was measured by determining the hydrogen donating or radical scavenging ability of the stable 1, 1-diphenyl-2-picrylhydrazyl (DPPH) free radical followed the method of. ${ }^{18}$ Briefly, various concen- trations $(5-100 \mu \mathrm{g} / \mathrm{mL})$ of the plant extract and standard (BHT) were added to the methanolic solution of DPPH $(0.2 \mathrm{mM})$ and the reaction mixture was throughly mixed and incubated in dark at room temperature for 10 minutes. The absorbance was read at $517 \mathrm{~nm}$ using spectrophotometer (Shimadzu UV-1800, Japan) and the percent inhibition was calculated as:

$$
\% \text { inhibition }=\frac{\mathrm{A}_{\text {control }}-\mathrm{A}_{\text {simple }}}{\mathrm{A}_{\text {Control }}} \times 100
$$

In order to determine $\mathrm{RS}_{\mathrm{a} 50}$ value, i.e, amount of sample required to cause $50 \%$ inhibition of DPPH radical, the scavenging Percentage was plotted against logarithmic values of concentration and a linear regression equation, $\mathrm{Y}=\mathrm{mx}+\mathrm{C}$ was established.

\section{$\mathrm{H}_{2} \mathrm{O}_{2}$ radical scavenging activity}

$\mathrm{H}_{2} \mathrm{O}_{2}$ scavenging activity of the various extracts was estimated followed the modified protocol of. ${ }^{19}$ Different extract concentrations (10-50 $\mu$ g/ $\mathrm{ml}$ ) was added to $600 \mu \mathrm{L}$ of $\mathrm{H}_{2} \mathrm{O}_{2}$ solution $(40 \mathrm{mM})$ in phosphate buffer $(0.1 \mathrm{M}, \mathrm{pH}=7.4)$. Incubate the reaction mixture at $25^{\circ} \mathrm{C}$ for $10 \mathrm{~min}$ and then read at 230nm using UV- spectrophotometer against a solution blank containing only phosphate buffer. The $\mathrm{H}_{2} \mathrm{O}_{2}$ scavenging activity of the extract was calculated by using the formula:

Hydrogen peroxide scavenging activity $(\%)=\left[\left(\mathrm{A}_{0}-\mathrm{A}_{1}\right) / \mathrm{A}_{0}\right] \times 100$

Where $\mathrm{A}_{0}$-control absorbance and $\mathrm{A}_{1}$-sample absorbance

\section{Sample preparation for atomic absortion spectrophotometry (AAS)}

Fresh seeds samples were dried at $55^{\circ} \mathrm{C}$ for $72 \mathrm{~h}$, mechanically grinded and sifted out with a mesh $(178 \mu \mathrm{m})$. Wet ashing was done following the protocol of ${ }^{20}$ by taking $0.25 \mathrm{~g}$ of powdered groat samples in a separate $50 \mathrm{ml}$ flask containing mixed acid solution [nitric acid $\left(\mathrm{HNO}_{3}\right.$ : sulfuric acid $\mathrm{H}_{2} \mathrm{SO}_{4}$ : perchloric acid $\left.\left(\mathrm{HClO}_{4}\right)\right]$ in a ratio of 5:1:0.5. The samples were boiled in acid solution on hot plate under fume hood till the organic matter is completely digested as indicated by white fumes coming out from the flask. Thereafter, few drops of ultrapure water were added and allowed to cool. The volume of the digestion solution was adjusted to $50 \mathrm{ml}$ with ultrapure water. The solution was filtered and submitted to AAS (Perkin Elmer USA) analysis.

\section{Statistical analysis}

The results are presented as mean \pm standard deviation (SD) of three replicates and data were subjected to analysis of variance using Graph pad prism 6.07 software and was considered significant at $p<0.05$. $\mathrm{RS}_{\text {a50 }}$ values were calculated by using linear regression plots.

\section{RESULTS AND DISCUSSION}

\section{Total phenol and flavonoid content}

The TPC and TFC of the F. tataricum and F. kashmirianum are presented in Figure 1a, b. From the results the aqueous extract of $F$. tataricum shows better TPC $(159.51 \pm 10.3 \mathrm{mg} \mathrm{GAE} / \mathrm{g} \mathrm{DW})$ and TFC $(79.49 \pm 9.76 \mathrm{mg}$ $\mathrm{RE} / \mathrm{g} \mathrm{DW}$ ) as compared to F. kashmirianum. It has been reported that rich flavonoid and phenolic plants could be a vital source of therapeutic potential against the oxidative damages by scavenging free radicals. ${ }^{21-24}$ Previous study also reports that secondary metabolites act as strong chain breaking antioxidants. ${ }^{23}$ Our results are in accordance with Mann et al. ${ }^{25}$ using a comparative nutritional and antioxidant potential of two 
buckwheat species. Earlier reports also revealed that TPC of tartary buckwheat was much higher than that of cranberry, apple, ${ }^{26}$ raspberry, ${ }^{27}$ honey, ${ }^{28}$ corn, wheat, oats and rice ${ }^{29}$ suggesting that tartary buckwheat may serve as an excellent dietary source of phenolics. Earlier studies have also reported that the TPC and TFC of the plants are influenced by environmental factors as well as the type of species. ${ }^{30}$ The present study reveals that the buckwheat grown in Kashmir region is a potential source of phenolic and flavonoids bioactive constituents, thus could be used as an excellent source of functional food.

\section{Total antioxidant activity}

Total antioxidant activity of the plant extract was determined in terms of ferric reducing antioxidant power assay (FRAP) i.e, capability of the plant extract to convert $\mathrm{Fe}^{3+}$ to $\mathrm{Fe}^{2+}$. In this assay, formation of blue color due to the reduction of Fe (III)-TPTZ complex into Fe (II)-TPTZ complex that absorbs strongly at $593 \mathrm{~nm}$. The reducing property of extract is associated with the presence of metabolites that are involved in breaking the free radical chain reaction by donating $\mathrm{H}$-atom. ${ }^{31,32}$ The present results reveal that the ferric reducing power of both the buckwheat species increased in a concentration-dependent manner (Figure 1c). Similar observation was also reported in Samac (Rhus coriaria L.) that shows an increase in ferric reducing power ability as the concentration increases. ${ }^{33}$ Results show that aqueous leaf extract of $F$. kashmirianum shows better ferric reducing power $(350.68 \pm 15.89 \mu \mathrm{M} \mathrm{Fe}(\mathrm{II}) / \mathrm{g} \mathrm{DW})$ as compared to F. tataricum $(295.08 \pm 10.86 \mu \mathrm{M}$ Fe (II)/g DW). Technically, FRAP assay

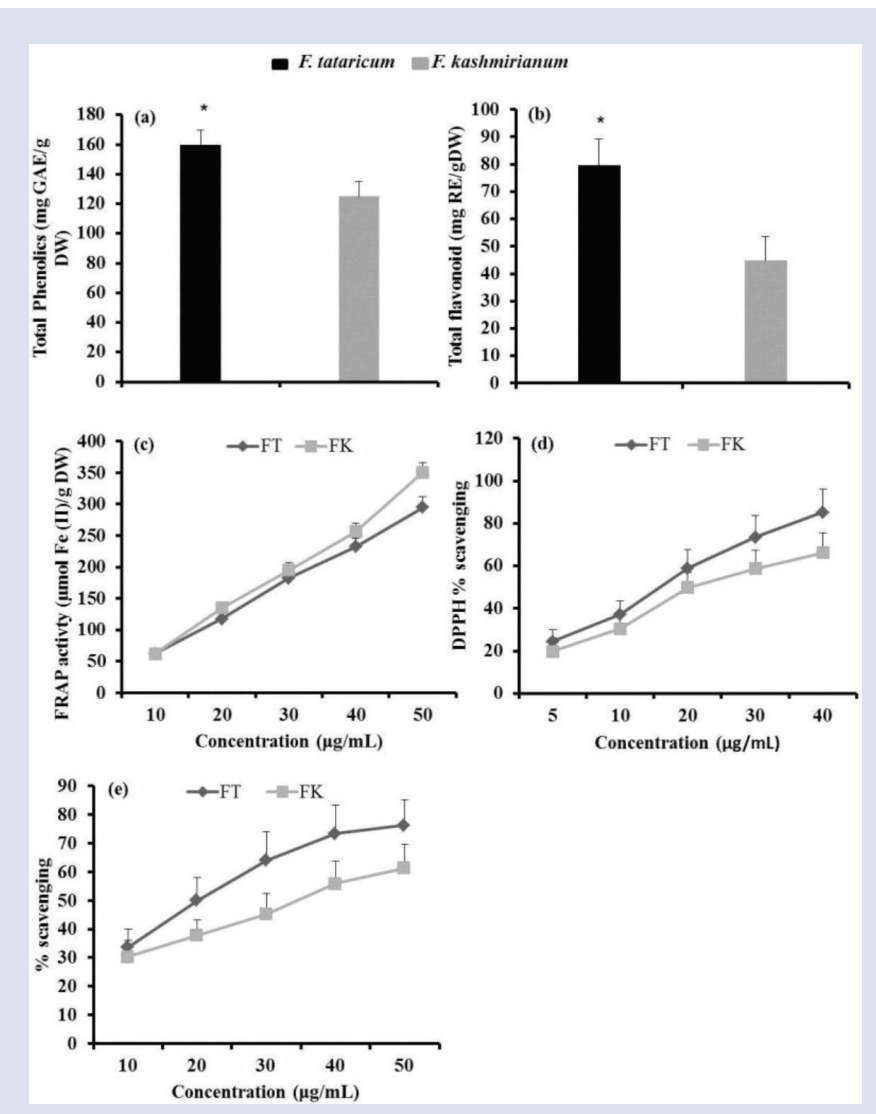

Figure 1: stimation of total phenol (a) flavonoid content (b) FRAP assay (c) DPPH radicle scavenging activity (d) and $\mathrm{H}_{2} \mathrm{O}_{2}$ radical scavenging activity (e) of aqueous leaf extract of F. tataricum and $F$. kashmirianum. Data represents mean $\pm \mathrm{SD}(\mathrm{n}=3)$. Significant at $P<0.05$. is simple to determine the total antioxidant potential of the plant extract and is a proven quantitative approach to determine potential of various phyto-foods. ${ }^{34}$ Our results are in accordance with earlier studies of Mann et $a l^{25}$

\section{DPPH assay}

To evaluate the free radical scavenging power of the plant extract, DPPH assay is a widely accepted protocol and is based on the reduction of methanolic DPPH solution in the presence of antioxidant resulting in the formation of non-radical DPPH-H by the reaction and the degree of discoloration exhibited by the scavenging potential of the extract. DPPH radical scavenging activity of the aqueous leaf extract of two buckwheat species are depicted in Figure 1d. From the results, the data shows that in both the species the radical scavenging activity of leaf extract increases in a dose-dependent manner. Among the two buckwheat species, $F$. tataricum exhibits high scavenging activity $(85.10 \% \pm 10.78)$ at $40 \mu \mathrm{L}$ concentration as compared to F. kashmirianum $(66.23 \% \pm 8.76)$ over that same concentration. The present study also revealed that $F$. tataricum exhibits lower radical scavenging activity $\left(\mathrm{RS}_{\mathrm{a} 50}=26.67 \mu \mathrm{g} / \mathrm{mL}\right)$ as compared to $F$. kashmirianum $\left(\mathrm{RS}_{250}=34.15 \mu \mathrm{g} / \mathrm{mL}\right.$ ) which is associated with the high percentage of scavenging of free radicals. ${ }^{35}$ reported that plants with antioxidant capacity exhibit better radical scavenging activity. The present study confirms that aqueous leaf extract of tartary buckwheat is a potent antioxidant as compared to F. kashmirianum. It also suggests that the plant extracts containing bioactive constituents that are able to donate $\mathrm{H}$-atom to a free radical which in turn remove odd electron that is responsible for the radical's reactivity ${ }^{35}$ Our findings are in accordance with earlier reports. ${ }^{36,37}$

\section{Hydrogen peroxide radical scavenging activity}

$\mathrm{H}_{2} \mathrm{O}_{2}$ itself is not very toxic to cellular system but sometimes it becomes toxic as it is directly involved in the Fenton's reactions that leads to the production of $\mathrm{OH}^{--}$radicals. ${ }^{38,39}$ From the results, the $\mathrm{H}_{2} \mathrm{O}_{2}$ scavenging activity of the aqueous extract of both buckwheat species increases with increase in concentration and was found high in F. tataricum $(76.28 \pm 8.785)$ at $50 \mu \mathrm{g} / \mathrm{ml}$ concentration as compared to F. kashmirianum $(61.34 \pm 7.67 \%)$ over the same concentration (Figure 1e). The $\mathrm{RS}_{\mathrm{a} 50}$ value of aqueous extract of $F$. tataricum was found to be $21.32 \mu \mathrm{g} / \mathrm{ml}$ compared to F. kashmirianum $(34.81 \mu \mathrm{g} / \mathrm{ml})$. The strong $\mathrm{H}_{2} \mathrm{O}_{2}$ scavenging activity of the buckwheat leaf extract may be due to the presence of secondary metabolites like phenolic compounds and other metabolites such as, tannins, anthocyanins which donates electron to $\mathrm{H}_{2} \mathrm{O}_{2}$ radicles thus neutralizing their effect. ${ }^{40}$ These results suggest that aqueous extract can be a better antioxidant for removing $\mathrm{H}_{2} \mathrm{O}_{2}$ and thus protecting living systems under oxidative stress.

\section{Macro-and micro-nutrient analysis}

The various mineral element concentrations in the groat samples of two buckwheat species are presented in Figure 2a-k. A comparative macroand micro-nutrient analysis of the groat samples was done among two buckwheat species (F. tataricum and F. kashmirianum) and the results revealed that $F$. tataricum contains highest $\mathrm{Ca}$ level $(5125 \pm 56.76 \mathrm{ppm})$ as compared to F. kashmirianum (4055 $\pm 45.67 \mathrm{ppm})$. Ca plays a significant role in muscular contraction, provides strength to bones and reduces the risks of osteoporosis. ${ }^{41} \mathrm{Fe}$ was more abundant in the groat samples of F. kashmirianum $(1122.5 \pm 25.77 \mathrm{ppm})$ as compared to F.tataricum $(875 \pm 10.86 \mathrm{ppm})$. Fe constitutes an important part of the hemoglobin, thus is necessary to overcome the problems of anemia, besides it also maintains the function of central nervous system (CNS). ${ }^{42} \mathrm{Fe}$ is also important to prevent cough linked with angiotensin-converting enzyme inhibitors. ${ }^{43}$ The micro-nutrient $\mathrm{Zn}$ constitutes an important co-factor 


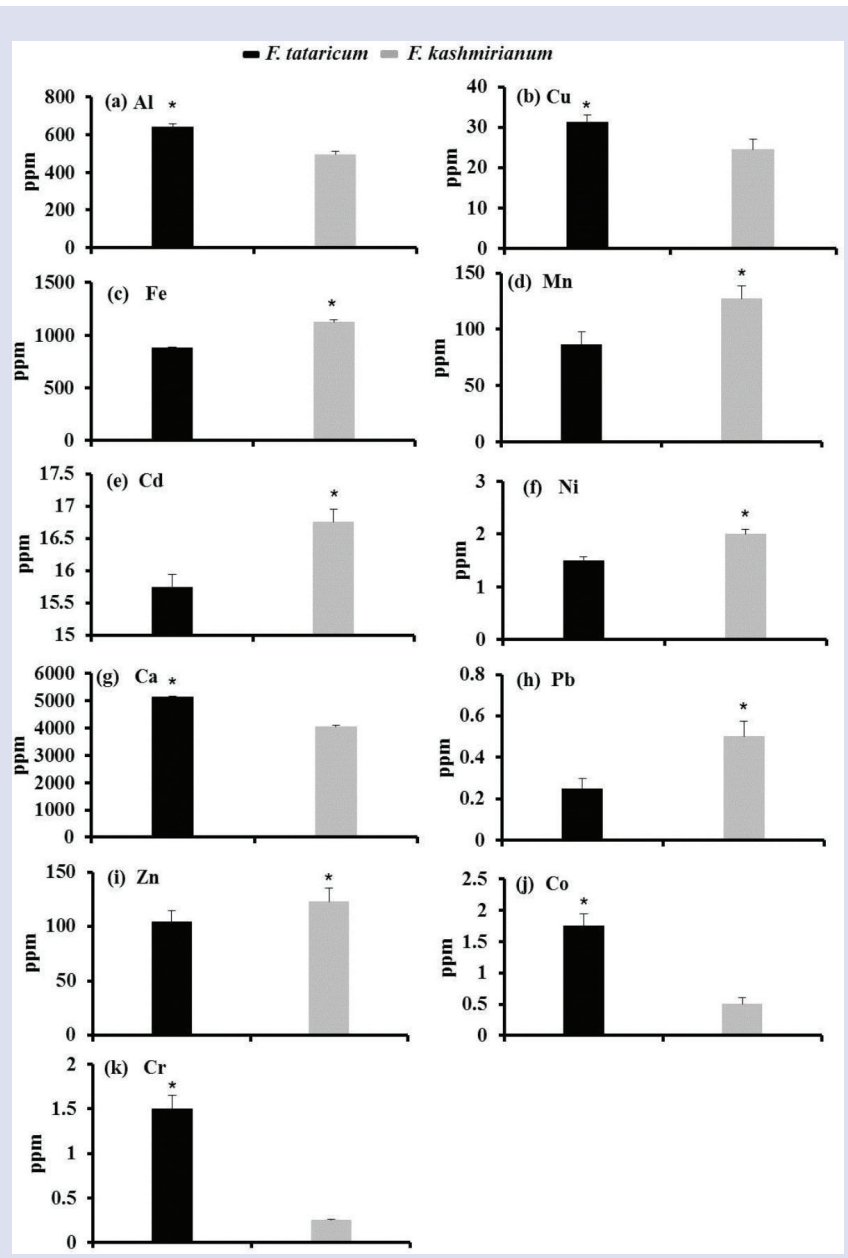

Figure 2 :Element concentrations in the groat samples of two buckwheat species (ppm). *Asterisk represents significant at $P<0.05$

of various enzymes. Deficiency of $\mathrm{Zn}$ especially in children leads to retardation in growth, loss of appetite, general indisposition and skin related disorders. ${ }^{44}$ Our results show that F. kashmirianum contains more amount of $\mathrm{Zn}(122.75 \pm 12.34 \mathrm{ppm})$. Another micro-nutrient manganese $(\mathrm{Mn})$ is very essential to improve insulin sensitivity and is the structural component of many enzymes. ${ }^{45}$ The present study shows that Mn was high in F. kashmirianum $(127.27 \pm 11.55 \mathrm{ppm})$. Copper $(\mathrm{Cu})$ also takes part in various metabolisms and the deficiency of this mineral element leads to microcytic anemia, neutropenia and deformation of bones. ${ }^{46}$ Among two buckwheat species $\mathrm{Cu}$ was found high in $\mathrm{F}$. tataricum $(31.25 \pm 1.89 \mathrm{ppm})$. Cr plays a vital role regulating blood-glucose level, hunger, cholesterol level and also protects DNA. ${ }^{41}$ Results reveal that $\mathrm{Cr}$ was found high in F. tataricum $(1.5 \pm 0.15 \mathrm{ppm})$. Other micro-nutrients such as nickle $(\mathrm{Ni})$ and cobalt $(\mathrm{Co})$ are required by human body in little amount. $\mathrm{Co}$ is an essential component of vitamin $\mathrm{B}_{12}$ and thyroid metabolism. ${ }^{47}$ In the present study, F. tataricum contains higher Co-content $(1.75 \pm 0.2 \mathrm{ppm})$. Lead $(\mathrm{Pb})$, Aluminium $(\mathrm{Al})$ and Cadmium $(\mathrm{Cd})$ are considered as toxic elements and their presence in the groat samples of buckwheat is due to the degraded quality of the soil.

\section{CONCLUSION}

From the present investigation, it was concluded that the aqueous extract of tartary buckwheat possesses high antioxidant and free radical scavenging activity. These in vitro assays indicate that the buckwheat plant extract is a significant source of natural antioxidant which might be useful in preventing the progress of various oxidative stresses. Further, the macro-and micro-nutrient analysis of buckwheat groat samples revealed that it is rich in calcium, iron and zinc and thus could be used as a potential biofortified crop for reducing mal-nutrition especially among impoverished regions of the world. The study also revealed that among two buckwheat species, tartary buckwheat is efficient in terms of antioxidant potential and mineral element analysis.

\section{ACKNOWLEDGEMENT}

RUR is thankful to University of Kashmir (UoK) for providing the Seed Grant. Thanks to the staff at University Science and Instrumentation Centre (USIC) for elemental analysis.

\section{CONFLICT OF INTEREST}

The authors declare no conflict of interest.

\section{ABBREVIATIONS}

AAS: Atomic Absorption Spectrophotometry; AOS: Active Oxygen Species; BHT: Butylated hydroxyl toluene; DNA: Deoxyribonucleic acid; DPPH: 1, 1-diphenyl-2-picrylhydrazyl; DW: Dry Weight; FRAP: Ferric Reducing Antioxidant Potential; FAO: Food and Agricultural Organization RS : Radical Scavenging activity; TPTZ: 2, 4, 6-tripyridyl-s-triazine; TFC: Total Flavonoid Content; TPC: Total Phenol Content;

\section{REFERENCES}

1. Niki E. Assessment of antioxidant capacity in vitro and in vivo. Free Radical Biology and Medicine. 2010;49(4):503-15.

2. Schutzendubel A, Polle A. "Plant responses to abiotic stresses: heavy metal-induced oxidative stress and protection by mycorrhization,.. J Exp Bot. 2002;372(53):1351-65

3. Nilsson J, Stegmark R, Akesson B. Total antioxidant capacity in different pea (Pisum sativum) varieties after blanching and freezing. Food Chem. 2004; 86(4):501-7.

4. Shen $\mathrm{Q}$, Zhang $\mathrm{B}, \mathrm{Xu} \mathrm{R}$, Wang Y, Ding $X$, Li P. Antioxidant activity in vitro of the selenium-contained protein from the Se-enriched Bifidobacterium animalis 01. Anaerobe. 2010;16(4):380-6

5. Gosslau A, Chen KY. Nutraceuticals, apoptosis, and disease prevention. Nutrition. 2004;20(1):95-102.

6. Tayade AB, Dhar P, Sharma M, Chauhan RS, Chaurasia OP, Srivastava RB. Antioxidant capacities, phenolic contents, and GC/MS analysis of Rhodiola imbricata Edgew. root extracts from Trans-Himalaya. J Food Sci. 2013;78(3):402-10.

7. Maestri DM, Nepote V, Lamarque AL, Zygadlo JA. Natural products as antioxidants. In Imperato F. (Eds). Phytochemistry: Advances in Research. 2006.p.105-35. Trivandrum: Research Signpost.

8. Jiang P, Burczynski F, Campbell C, Pierce G, Austria JA, Briggs CJ. Rutin and flavonoid contents in three buckwheat species Fagopyrum esculentum, $F$. tataricum, and F. homotropicum and their protective effects against lipid peroxidation. Food Res Int. 2007;40(3):356-64

9. Pirzadah TB, Malik B, Tahir I, Rehman RU. Buckwheat: an introspective and future perspective in Kashmir Himalayas. In Germ M, Kreft I, Vogrincic M, Vombergar B. (Eds). Proceedings of the 12th International Symposium on Buckwheat,p.212-5. Laško, 2013;21-5. Pernica: Fagopyrum.

10. Farooq S, Rehman RU, Pirzadah TB, Malik B, Dar FA, Tahir I. Cultivation, Agronomic Practices, and Growth Performance of Buckwheat. Molecular Breeding and Nutritional Aspects of Buckwheat. 2016.p.299-320. Elsevier Inc.

11. Alvarez-Jubete L, Arendt EK, Gallagher E. Nutritive value of pseudocereals and their increasing use as functional gluten-free ingredients. Trends Food SciTechnol. 2010;21(2):106-13

12. Bonafaccia G, Marocchini M, Kreft I. Composition and technological properties of the flour and bran from common and tartary buckwheat. Food Chem. 2003; 80(1):9-15.

13. Mestek O, Polak J, Koplik R, Kominkova J, Santrucek J, Kodicek M, et al. Analysis of element species fractions in buckwheat and amaranth flours by SEC/ICP-MS and MALDI-MS. Eur Food Res Technol. 2007;225(5-6):895-904

14. Okogun Jl. Methods of Medicinal Plant Extract Preparation. National Institute for Pharmaceutical Research and Development (NIPRD). 2000.p.135-8. Idu-Abuja, Nigeria. 
15. Mallick CP, Singh MB. In Plant Enzymology and Histo Enzymology (Eds). 1980.p.53. Kalyani Publishers, New Delhi.

16. Hung PV, Morita N. Distribution of phenolic compounds in the graded flours milled from whole buckwheat grains and their antioxidant capacities. Food Chem. 2008;109(2):325-31.

17. Benzie IFF, Strain JJ. The ferric reducing ability of plasma (FRAP) as a measure of "antioxidant power": the FRAP assay. Anal Biochem. 1996;239(1):70-6.

18. Braca A, Tommasi ND, Bari LD, Pizza C, Politi M, Morelli I. Antioxidant principles from Bauhinia terapotensis. J Nat Prod. 2001;64(7):892-5.

19. Nabavi SM, Ebrahimzadeh MA, Nabavi SF, Hamidinia A, Bekhradnia AR. Determination of antioxidant activity, phenol and flavonoids content of Parrotia persica Mey. Pharmacologyonline. 2008;2:560-7.

20. Ang H, Lee K. Analysis of mercury in Malaysian herbal preparations: a peerreview. Biomed Sci. 2005;4:31-6.

21. Pourmorad F, Hosseinimehr SJ, Shahabimajd N. Antioxidant activity, phenol and flavonoid contents of some selected Iranian medicinal plants. Afr J Biotechnol. 2006;5(11):1142-5.

22. Adedapo AA, Jimoh FO, Afolayan AJ, Masika PJ. Antioxidant activities and phenolic contents of the methanol extracts of the stems of Acokanthera oppositifolia and Adenia gummifera. BioMedCentral Complem Alternat Med. 2008;8(1):54-60

23. Dhar P, Bajpai PK, Tayade AB, Chaurasia OP, Srivastava RB, Singh SB. Chemical composition and antioxidant capacities of phytococktail extracts from transHimalayan cold desert. BioMedCentral Complem Alternat Med. 2013;13(1):259.

24. Bursal E, Koksal E, Gulcin I, Bilsel G, Goren AC. Antioxidant activity and polyphenol content of cherry stem (Cerasus avium L.) determined by LCMS/ MS. Food Res Int. 2013;51(1):66-74.

25. Mann S, Gupta D, Gupta PK. Evaluation of nutritional and antioxidant potential of Indian Buckwheat grains. Ind J Trad Know. 2012;11(1):40-4.

26. Sun J, Chu YF, Wu XZ, Liu RH. Antioxidant and antiproliferative activities of common Fruits. J Agric Food Chem. 2002;50(25):7449-54.

27. Socha R, Juszczak L, Pietrzyk S, Fortuna T. Antioxidant activity and phenolic composition of herb honeys. Food Chem. 2009;113(2):568-74.

28. Idris YMA, Mariod AA, Hamad SI. Physicochemical properties, phenolic contents and antioxidant activity of Sudanese honey. Int J Food Prop. 2011;14(2):450-8.

29. Adom KK, Liu RH. Antioxidant activity of grains. J Agric Food Chem 2002:50(21):6182-7.

30. Pantelidis GE, Vasilakakis M, Manganaris GA, Diamantidis G. Antioxidant capacity, phenol, anthocyanin and ascorbic acid contents in raspberries, blackberries, red currants, gooseberries and Cornelian cherries. Food Chem. 2007;102(3):777-83.

31. Duh P, Du P, Yen G. Action of methanolic extract of mung bean hull as inhibitors of lipid peroxidation and non-lipid oxidative damage. Food Chem Toxicol. 1999; 37(11):1055-61.

32. Guo C, Yang J, Wei J, Li Y, Xu J, Jiang Y. Antioxidant activities of peel, pulp and seed fractions as determined by FRAP assay. Nutrition Res. 2003;23(12):1719-26.

33. Ercan B, Ekrem K. Evaluation of reducing power and radical scavenging activities of water and ethanol extracts from sumac (Rhus coriaria L.) Food Res Int. 2011; 44(7):2217-21.

34. Ou B, Huang D, Hampsch-Woodill M, Flanagan JA, Deemer EK. Analysis of antioxidant activities of common vegetables employing oxygen radical absorbance capacity (ORAC) and ferric reducing antioxidant power (FRAP) assays: a comparative study. J Agric Food Chem. 2002;50(11):3122-8.

35. Olayinka AA, Anthony IO. Preliminary phytochemical screening and In vitro antioxidant activities of the aqueous extract of Helichrysum longifolium DC. BioMedCentral Complem Alternat Med. 2010;10(1):21.

36. Lin LY, Liu HM, YuYW, Lin SD, Mau JL. Quality and antioxidant property of buckwheat enhanced wheat bread. Food Chem. 2009;112(4):987-91.

37. Sedej I, Sakac M, Mandic A, Misna A, Pestoric M, Simurina O, et al. Quality assessment of gluten-free crackers based on buckwheat flour. LWT-Food Sci Technol. 2011;44(3):694-9.

38. Kumaran A, Karunakaran RJ. In vitro antioxidant properties of methanol extracts of five Phyllanthus species from India. Food Sci Technol. 2007:4(2):344-52

39. Sahreen S, Khan MR, Khan RA. Phenolic compounds and antioxidant activities of Rumex hastatus D. Don. Leaves. J Med Plant Res. 2011;5(13):2755-65.

40. Ebrahimzadeh MA, Nabavi SM, Nabavi SF, Eslami B, Ehsanifar S. Antioxidant activity of Hyoscyamus squarrosus fruits. Pharmacologyonline. 2009;2:644-50.

41. Khan KY, Khan MA, Niamat R, Munir M, Fazal H, Mazari P, et al. Element content analysis of plants of genus Ficus using atomic absorption spectrometer. Afr J Pharm Pharacol. 2011;5(3):317-21.

42. Beard J, Tobin B. Iron status and exercise. Am J Clin Nut. 2000;72(2):594S-7.

43. Soetan KO, Olaiya CO, Oyewole OE. The importance of mineral elements for humans, domestic animals and plants: A review. Afr J Food Sci. 2010;4(5):200-22.

44. Subramanian R, Subbramaniyan $P$, Raj V. Determination of some minerals and trace elements in two tropical medicinal plants. Asian Pacific J Trop Biomed. 2012;2(2):S555-8.

45. Saracoglu S, Tuzen M, Soylak M. Evaluation of trace element contents of dried apricot samples from Turkey. J Hazard Matter. 2009;167(1):647-52.

46. Linder MC, Hazeg-Azam M. Copper biochemistry and molecular biology. Am J Clin Nutr. 1996;63(5):797S-811.

47. Niamat R, Khan MA, Khan MY, Ahmad M, Ali B, Mazari P, et al. Element Content of Some Ethnomedicinal Ziziphus Linn. Species Using Atomic Absorption Spectroscopy Technique. J App Pharma Sci. 2012;2(3):96-100.

\section{GRAPHICAL ABSTRACT}

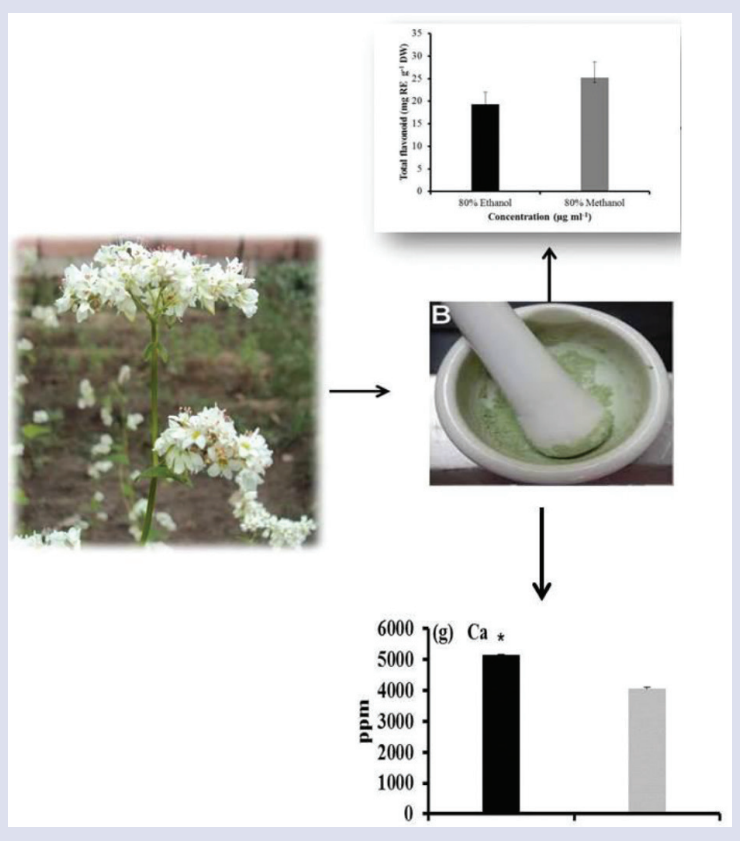

\section{SUMMARY}

- Buckwheat is one of the important crops that have gained a rapid momentum in the functional food sector due to its high neutraceutical properties.

- Ionomic analysis revealed important macro-and micro-nutrients that are indispensable for human health.

\section{ABOUT AUTHORS}

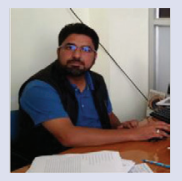

Dr. Reiaz UI Rehman: Is currently working as an Assistant Professor, Department of Bioresources, University of Kashmir, Srinagar, India. He was awarded PhD (Plant Biotechnology) in 2003 by Jamia Hamdard, New Delhi. Dr. Reiaz UI Rehman has about 14 years of teaching/research experience in plant biology. He is a recipient of several fellowships at both national and international level, particularly, the award of the Marie Curie IIF project (MC-IIF-FP7-219339). He has to his credit one published book and 22 publications in various national and international journals. 


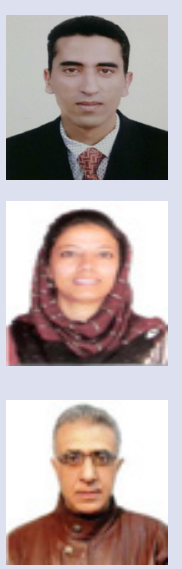

Tanveer Bilal Pirzadah: Is a PhD research scholar in the Department of Bioresources, University of Kashmir. He has worked on proteomics and stress biology in buckwheat, which is relevant to economical aspect in terms of crop productivity. He has to his credit 10 publications in international journals and 18 book chapters published by Springer and Elsevier publications. He has been awarded the Certificate from Elsevier Publishers, Netherland for his article among top 25 hottest articles on Science Direct (EEB) for three months (Third Rank).

Bisma Malik: Is a PhD Scholar in the Department of Bioresources, University of Kashmir. She has worked on proteomics and stress biology in chicory-an untapped Bioresource from Kashmir Himalaya. She has to her credit 5 publications in international journals and 18 book chapters published by Springer and Elsevier publications. She is the recipient of Women scientist (WOS-A) fellow from DST, India.

Dr. Inayatullah Tahir: Is currently working as a Professor, Department of Botany, University of Kashmir, Srinagar, India. He earned his PhD degree in Botany from Kashmir University in 1986. Prof. Inayatullah Tahir has more than 28 years of teaching and research experience. He has done extensive work pertaining to physiological studies on buckwheats in Kashmir. Buckwheat belonging to genus Fagopyrum is an important bioresource in view of its historical perspective and socio-economic benefits. He has also been actively perusing the research on flower senescence and postharvest physiology of the ornamentals. He has published more than 60 papers in various national and international journals. He has attended and presented his research findings in various national and international conferences; besides, he is life member of several learned scientific societies.

Cite this article: Pirzadah TB, Malik B, Tahir I, Rehman RUI. Antioxidant Potential and Ionomic Analysis of Two Buckwheat Species from Kashmir Region. Pharmacog J. 2018;10(6)Suppl:s83-s88. 